\title{
Wavelengths From Iron-Halide Lamps
}

\author{
Robert W. Stanley and William F. Meggers
}

\begin{abstract}
The history of secondary standards of wavelength for spectroscopic measurements is briefly reviewed. The present system of international secondary standards is based on interferometer determinations of wavelengths emitted by an electric arc between iron electrodes at atmospheric pressure; their uncertainty is of the order of 1 part in 3 million. It is shown that iron lines obtained from an electrodeless lamp, containing a minute amount of iron bromide, permit higher accuracy of wavelength measurement. The wavelengths of 103 radiations from such a lamp have been measured with Fabry-Perot interferometers. They range from 2954.8031 to $4064.7414 \mathrm{~A}$, and calculated probable errors, as well as atomicenergy intervals, indicate that the relative values are uncertain by only 1 part in 7 or 8 million.
\end{abstract}

\section{Introduction}

For nearly 70 years the electric arc between iron electrodes has served as a source of standard wavelengths for spectroscopic measurements. During this time many efforts were made to improve the precision and extend the spectral range of these standards. These efforts will be briefly reviewed because they justify the determination of wavelengths from iron-halide lamps to be described in the present paper.

In 1888 Kayser and Runge [1] ${ }^{1}$ adopted the are spectrum of iron as a scale of wavelengths for the measurement of other spectra; they published the first useful atlas of the iron-arc spectrum and determined the relative wavelengths of about 4,500 lines ranging from 2230.01 to $6750.36 \mathrm{~A}$. These wavelengths were based on Rowland's Atlas of the Solar Spectrum, but most of the values were obtained by interpolation or extrapolation in normal spectra from concave diffraction gratings. In fact, excepting the absolute measurement of three cadmium wavelengths by Michelson, all determinations of standard wavelengths prior to 1902 were made with diffraction gratings by measuring grating spacing, diffraction angles, and overlapping spectral orders.

A new era of standards began in 1902 when a simpler method, capable of greater accuracy in comparing wavelengths, was conceived by Fabry and Perot [2]; it is based upon the fact that the double distance between two plane and parallel interferometer plates may be expressed as the product of any wavelength and its order of interference. Thus, the ratio of any two wavelengths is given by the inverse ratio of their orders. Fabry and Perot [2] pointed out that the relative wavelengths obtained from such interference patterns have relative errors dependent only on the orders of interference, and with infinitely sharp lines one could increase the precision indefinitely by increasing the orders of interference. In practice these orders are always limited by the actual widths of spectral lines; indeed, the Fabry-Perot interferometer was shown by Buisson and Fabry [3] to be an ideal instrument for measuring spectral line widths, or coherence limits of spectral radiations.

1 Figures in brackets indicate the literature references at the end of this paper.
In 1905 the International Union for Cooperation in Solar Research [4] proposed that a primary standard of wavelength be adopted, and that secondary standards at 50-A intervals in the arc spectrum of iron be determined by the interference method devised by Fabry and Perot. In 1907 the Union adopted [5] as the primary standard 6438.4696 A, the wavelength of red radiation from cadmium measured relative to the meter by Benoit, Fabry, and Perot, and in 1910 the Union adopted [6] 49 secondary standards ranging from 4282.408 to $6494.993 \mathrm{~A}$, the values being the means of three independent, concordant determinations.

After World War I, responsibility for secondary standards of wavelength was assumed by the International Astronomical Union, which, in 1922, adopted [7] 80 iron wavelengths ranging from 3370.789 to 6750.163 A. Wavelengths from iron arcs measured before 1921 suggested that some of the values were sensitive to operating conditions, which led to a precise specification $\left[7_{j}\right.$ of the light source. "In order to obtain lines of constant wavelength, constant intensity distribution, and adapted to high orders of interference, the adoption is recommended of the Pfund arc operated between 110 and 250 volts, with 5 amperes or less, at a length of 12-15 millimeters used over a central zone at right angles to the axis of the arc, not to exceed 1-1.5 millimeters in width, and with an iron rod 6-7 millimeters in diameter as the upper pole and a bead of oxide of iron as the lower pole. As the secondary standards to the red of $\lambda 6000$ are all stable lines, and as exposures with the above mentioned are may be rather long, it is recommended that the $6 \mathrm{~mm}$, 6 ampere are be retained for this region." When the wavelengths emitted by this specified iron arc were remeasured they were found to have slightly smaller values than the 1922 standards. In 1928, new values were adopted for 235 iron standards [8] ranging from 3370.787 to $6677.993 \mathrm{~A}$, and in 1938 the number was increased [9! to 306 and the range extended to $2447.708 \mathrm{~A}$. Individual values of iron wavelengths from 2100.794 to $10216.351 \mathrm{~A}$ had been reported, but further progress was interrupted by World War II. However, in recent years additional measurements were made, so that by 1955 [10] the means of three or more concordant determinations existed for 575 iron lines between 2501.133 and 
9372.904 A. It required more than half a century to accumulate these measurements of wavelengths emitted by the standard iron arcs, and it is not likely that any more will be made, because spectroscopy now needs standards of higher precision.

The present international iron-arc standards cannot be measured with higher accuracy because they are too wide. Their width is due mainly to Dopplereffect produced by very high temperature $\left(\sim 6,300^{\circ}\right.$ $\mathrm{K})$. Furthermore, collision broadening and pressure shifts are present because the arc is operated at atmospheric pressure. The interference patterns deteriorate with orders exceeding about 50,000, and most of the standards have been measured with orders of 20,000 to 30,000 . The only practical way to improve the iron standards is to replace the hightemperature arc in air by sources operating at lower temperatures and pressures. In 1928 the I. A. U. [8] recommended "that vacuum-arc and furnace spectra be investigated carefully to determine if their use will improve the system of secondary standards."

No interference measurements of wavelengths have ever been made of iron lines emitted by a low-pressure furnace, but Burns and Walters [11] have made many such measurements of lines excited in inclosed ares operated at low pressures $(\sim 4 \mathrm{~cm} \mathrm{Hg})$. The vacuum are of iron has never found favor with the I. A. U. [12], partly because of its inconvenience, and also because there was no conclusive proof that any substantial gain in accuracy of standard wavelengths would ensue by substituting the vacuum arc for the standard Pfund arc in air. Now it must be admitted that, excepting a reduction in pressure shifts and a slight gain in line sharpness, iron lines from a vacuum arc or evacuated furnace are still handicapped by large Doppler widths that limit the accuracy of measurement.

In 1939 Williams and Middleton [13] proposed that a water-cooled iron hollow cathode (Schüler lamp) containing helium be considered as a superior source of secondary standards of wavelength. The vacuum wavelengths of 47 iron lines (3286.7508 to 5371.4905 A) were measured with a reflection echelon of 40 plates, each $6.87 \mathrm{~mm}$ thick, so that the orders of interference ranged from 26,000 to 42,000. Because an inclosed iron arc, at reduced pressure, was regarded as too inconvenient for general use, the I. A. U. could not be expected to favor a more cumbersome source that required water cooling in addition to evacuation, and continuous circulation and purification of helium gas.

In 1955, a more convenient hollow iron cathode source was described by Crosswhite, Dieke, and Legagneur [14]. This source is exhausted, then filled with $3-\mathrm{mm}(\mathrm{Hg})$ pressure of pure neon, and sealed off with a side tube containing activated uranium to absorb gaseous impurities. The wavelengths of 189 iron lines between 3570.0964 and 5709.3780 A have been measured with 5 - and $15-\mathrm{mm}$ etalons by Stanley and Dieke [15].

Unfortunately, the advocates of hollow-iron cathode sources did not indicate exactly how much gain in line sharpness and precision of wavelength measurement could be expected, and, although the wave- lengths were reported to eight figures, the lines were not deliberately chosen to apply the combination principle as a general test of relative accuracy.

Recently a third type of iron source has been described by Corliss, Bozman, and Westfall [16], who prepared electrodeless metal-halide lamps by distilling a minute amount of volatile salt in an evacuated quartz tube, admitting $2 \mathrm{~mm}(\mathrm{Hg})$ of argon, and then sealing them off. Such lamps containing either iron chloride or iron bromide, when excited at ultra-high frequency $(2,450 \mathrm{Mc})$, emit the iron spectrum with intensity comparable to the Pfund arc and with less than half the line widths. Because these lamps operate at a low pressure, and a temperature below $800^{\circ} \mathrm{K}$, the iron lines produce good interference patterns at 2 to 4 times the orders of interference possible with the iron arc. Whereas the secondary standards of wavelength from the iron are were measured mostly with orders of 20,000 to 50,000 these wavelengths can be measured from electrodeless lamps with orders in excess of 150,000 .

The purpose of this paper is to demonstrate that a substantial gain in accuracy of standard wavelengths would ensue by substituting an electrodeless iron-halide lamp for the standard Pfund arc. The proof of increased accuracy is found in the improved constancy of spectral term intervals as shown by iron lines involving the two low-energy terms, $a^{5} \mathrm{D}$ and $a^{5} \mathrm{~F}$ of $\mathrm{Fe} \mathrm{I}$.

\section{Light Sources}

The iron source used in this investigation was an electrodeless discharge tube prepared by C. H. Corliss [16]. This lamp consists of a tube of Vycor containing a few milligrams of $\mathrm{FeBr}_{3}$ and helium gas at a pressure of $2 \mathrm{~mm}$ of $\mathrm{Hg}$. The discharge was excited at a frequency of $2,450 \mathrm{Mc}$ obtained from a commercial diathermy generator. Upon first lighting the tube, the helium spectrum appears. This is quickly followed by the bromine spectrum. After a warmup period of 15 to $60 \mathrm{sec}$, the iron spectrum becomes very bright and the helium and bromine spectra virtually disappear.

The source of primary standards was an NBSMeggers $\mathrm{Hg}^{198}$ lamp [17]. The lamp used contained argon at a pressure of approximately $3 \mathrm{~mm}$ of $\mathrm{Hg}$. The $\mathrm{Hg}^{198}$ tube was also excited at 2,450 Mc and was cooled at all times by a stream of air from a small blower.

\section{Experimental Method}

The interference spectrograms were obtained by means of a Fabry-Perot interferometer used in conjunction with a $21-\mathrm{ft}$ spectrograph in the Wadsworth mounting with reciprocal dispersion of $5 \mathrm{~A} / \mathrm{mm}$ in the first order. The optical arrangement was that usually employed in which the interferometer is mounted in a parallel beam outside the spectrograph. In every case both sources were photographed simultaneously, and radiation from both sources traveled along the same path through interferometer and spectrograph. The $\mathrm{Hg}^{198}$ lamp and the iron 


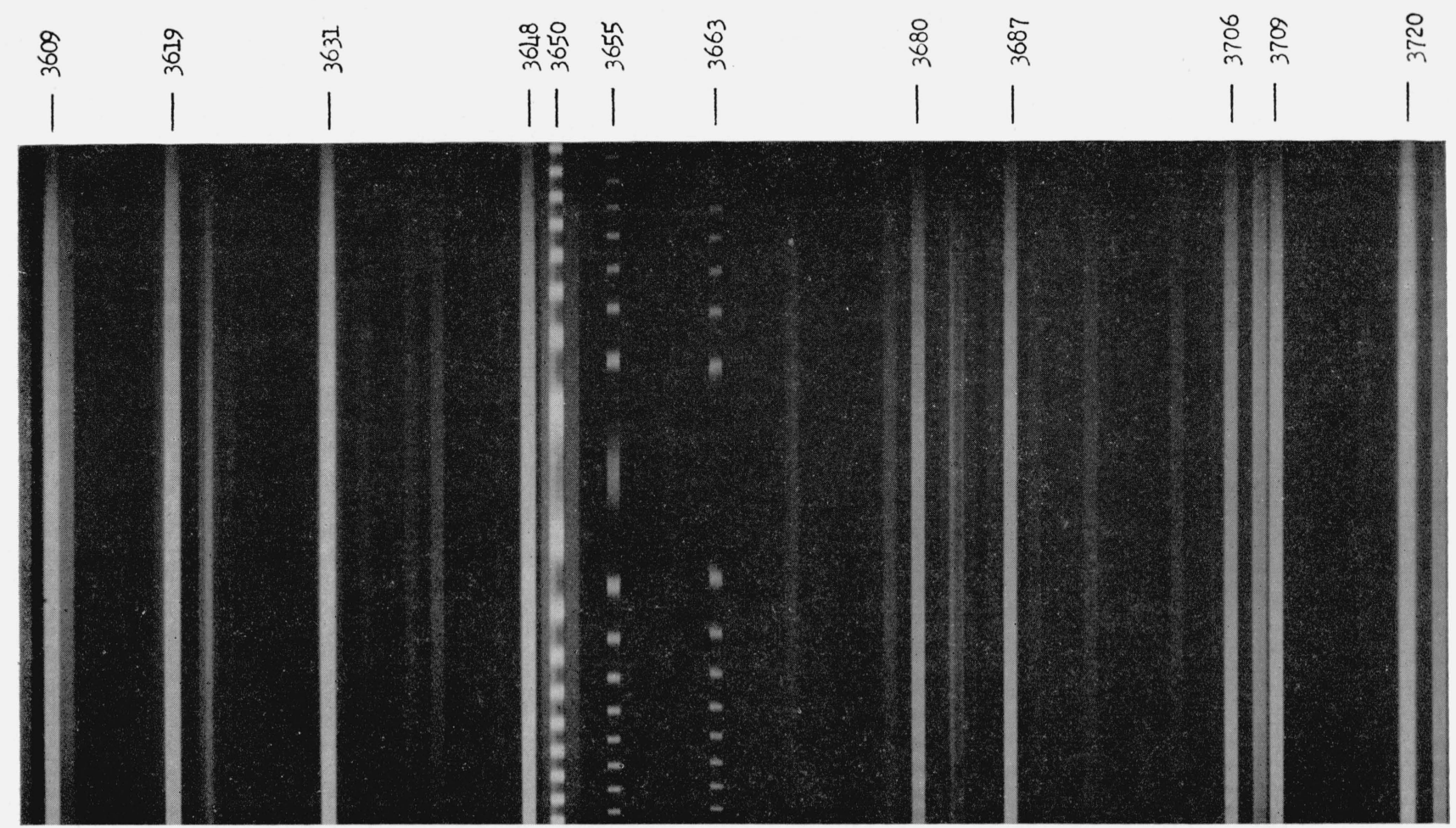

Figure 1. Fabry-Perot (25-mm etalon) spectrogram of international iron arc and mercury-198. Duration of exposure, $1.3 \mathrm{~min}$. The lines marked 3650, 3655, and 3663 belong to mercury-198.

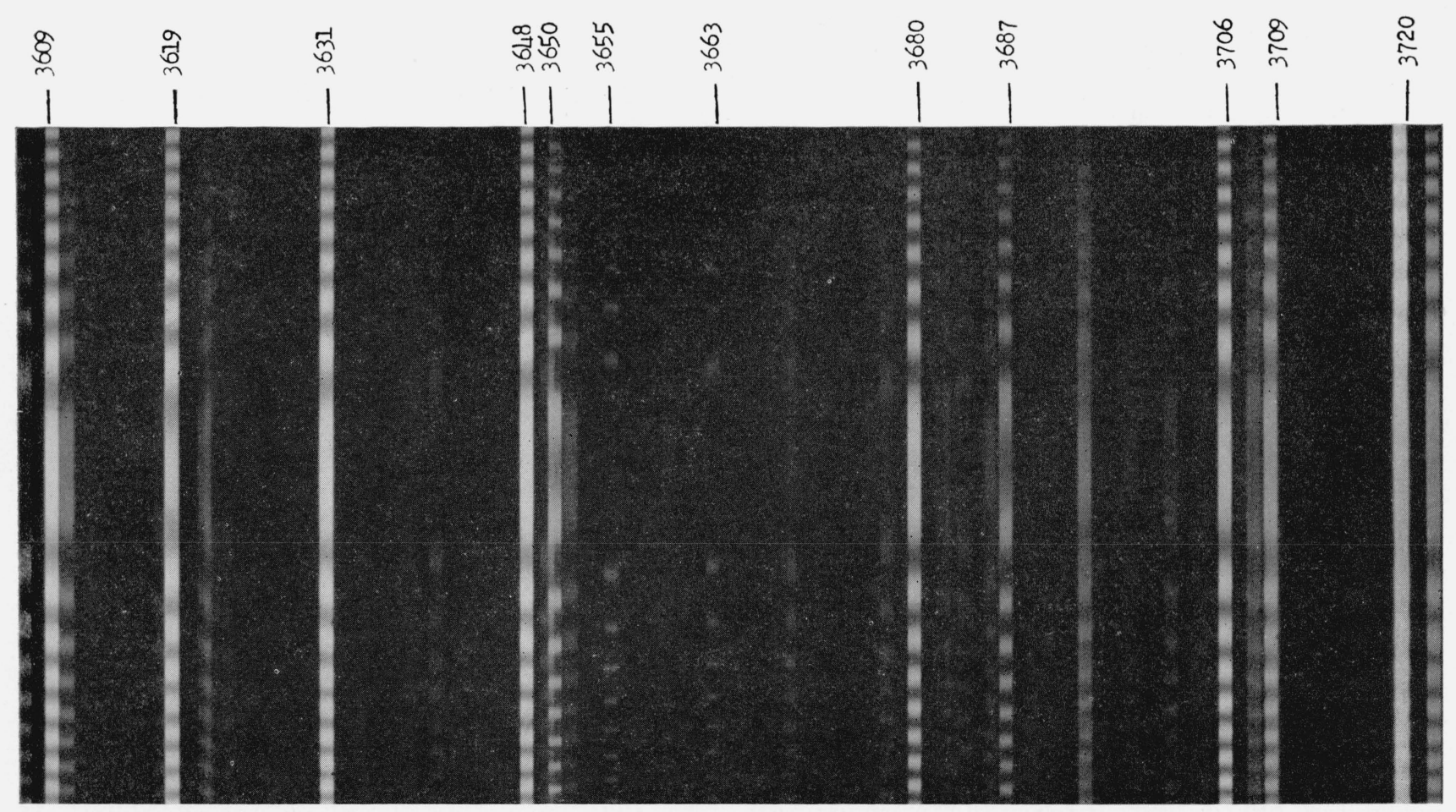

Figure 2. Fabry-Perot (25-mm etalon) spectrogram of iron-bromide lamp and mercury-198. Duration of exposure, 2 min. The lines marked 3650, 3655, and 3663 belong to mercury-198. 
lamp were placed on the optic axis with the iron lamp nearer the slit. A single lens was used to form an image of the $\mathrm{Hg}$ lamp inside the iron lamp. Radiation from both sources was rendered paralle] by means of a condensing lens placed between the iron tube and the spectrograph. The Fabry-Perot interferometer was placed in this parallel beam, and the Haidinger fringes produced by the interferometer were focused onto the slit jaws by means of a quartzfluorite achromat. With this arrangement, the two sources are also focused onto the slit. The accurate centering of the fringe pattern was accomplished by the usual autocollimation technique, using a light source at the mirror of the spectrograph.

Because the Wadsworth mounting produces some astigmatism away from the grating normal, it was necessary to change the curvature of the plate holder to correspond to the horizontal focus rather than the vertical focus. The required curvature is less than that which produces sharp images of the spectrograph slit. With this adjustment, it is possible to obtain sharp fringe patterns over a distance of 16 to 20 in.

Fabry-Perot interferograms were obtained in the spectral range 2950 to $4075 \mathrm{~A}$, using aluminized quartz plates, and plate separations of 20 or $25 \mathrm{~mm}$. Some photographs were taken with a $15-\mathrm{mm}$ separator to aid in the determination of integral orders. However, the final wavelengths are based on only the 20- and 25-mm measurements. Several photographs were obtained at each setting of the spectrograph with varying exposures and with slight changes of the interferometer spacing. The interferometer was evacuated to less than $10^{-3} \mathrm{~mm}$ of $\mathrm{Hg}$. The interferometer housing was insulated, and no change in the plate separation was observed during any exposure. The exposure times varied from $30 \mathrm{sec}$ to $15 \mathrm{~min}$, the average being $4 \mathrm{~min}$.

The reduction of the interferometer patterns was made from five diameters with the least squares calculation introduced by Rolt and Barrell [18]. The interference patterns were measured at the Bureau with the interference comparator designed by K. Burns [19], and at Clarkson College of Technology with a Gaertner traveling microscope especially adapted for the purpose. Sample spectrograms of the international iron arc and of the iron-bromide lamp are reproduced in figures 1 and 2 .

In the spectral range 2950 to $3400 \mathrm{~A}$, the $\mathrm{Hg}^{198}$ line of wavelength 3126.5763 A was used as primary standard both for the iron lines and the $\mathrm{Hg}$ lines that appeared on the plates. In the range 3400 to $4070 \mathrm{~A}$, the $\mathrm{Hg}^{198}$ line of wavelength $3655.8805 \mathrm{~A}$ was used as standard. All of the $\mathrm{Hg}$ lines that appeared with sufficient intensity and without serious interference from neighboring lines were measured along with the iron lines. The $\mathrm{Hg}^{198}$ lines that were measured are the following: 2968.1501, 3022.3798, 3342.4422, 3651.1967, 3664.3243, 4047.7144, and 4078.9891 A. All of the $\mathrm{Hg}^{198}$ wavelengths given above are vacuum wavelengths as produced by an NBS-Meggers $\mathrm{Hg}^{198}$ lamp containing argon at a pressure of $3 \mathrm{~mm}$ of $\mathrm{Hg}$ and are obtained from Kessler and Meggers [20]. The dispersion of phase correction was also obtained from Kessler and Meggers, who had used the same pair of plates in $\mathrm{Hg}^{198}$ measurements. After applying the dispersion of phase correction, the measured $\mathrm{Hg}^{198}$ wavelengths were found to be in excellent agreement with the above-stated values.

It has been found that small systematic discrepancies occur between the iron wavelengths calculated from two different interferograms, in spite of all efforts to eliminate the sources of such errors. It is believed that these systematic differences are due to the light from the two sources traveling slightly different paths through the interferometer. Because the parallelism cannot be made perfect, the spacing $2 t$ will be slightly different for the two sources if they do not both fill the interferometer uniformly. It is believed, however, that such systematic discrepancies are eliminated from the final wavelengths, which are based on several plates taken under different conditions.

\section{Results}

Table 1 gives the wavelengths of 103 iron lines between 2950 and $4070 \mathrm{~A}$. The measurements are based on 2 to 10 interferograms with etalons of 20 and $25 \mathrm{~mm}$. Each wavelength is followed by the number of observations and by the probable error when four or more observations are available. On the average, each line was measured between 5 and 6 times, and the average probable error is less than $0.0005 \mathrm{~A}$; this is the reason for giving each wavelength to four decimal places. The average probable error in these wavelengths is thus 1 part in 7 million. The last column gives the air wavelength of each of the measured lines. The index of refraction was obtained from the data of Edlén [21] and divided into the measured vacuum wavelength to give the corresponding wavelength in air.

The best available test of the consistency of wavelength measurements is afforded by the combination principle. The present set of lines was chosen specifically for the purpose of affording as many such checks as possible. As has been pointed out before [21], the combination principle is not useful for detecting a systematic error of the entire set of measurements. Table 2 contains energy-level differences obtained from the present vacuum wavelengths and, for comparison, the corresponding energy-level differences obtained from the measured wavelengths of the iron arc in air. The iron-arc lines that are used are only those that have been adopted as international secondary standards, that is, the final means of three (or more) independent and concordant observers, each of whom measured the lines a large number of times. The uncertainty in these adopted standards has been estimated to be of the order of 1 part in 3 million.

Ninety-eight of the 103 lines in table 1 are paired in table 2 to show the intervals between successive levels of the low-energy terms $a^{5} \mathrm{D}$ and $a^{5} \mathrm{~F}$ of $\mathrm{Fe} \mathrm{I}$. The average departure of each measured interval from the mean value is slightly more than $0.003 \mathrm{~K}$, which indicates that the average error in relative wave numbers is about 1 part in 8 million, or about the same as the average probable error in relative 
TABLE 1. Wavelengths of iron lines as measured in the electrodeless discharge tube

\begin{tabular}{|c|c|c|c|c|c|c|c|}
\hline $\begin{array}{l}\text { Measured vacu- } \\
\text { um wavelengths }\end{array}$ & $\begin{array}{l}\text { Observa- } \\
\text { tions }\end{array}$ & $\begin{array}{l}\text { Probable } \\
\text { error }\end{array}$ & $\begin{array}{l}\text { Air wave- } \\
\text { lengths }\end{array}$ & $\begin{array}{l}\text { Measured vacu- } \\
\text { um wavelengths }\end{array}$ & $\begin{array}{l}\text { Observa- } \\
\text { tions }\end{array}$ & $\begin{array}{l}\text { Probable } \\
\text { error }\end{array}$ & $\begin{array}{l}\text { Air wave- } \\
\text { lengths }\end{array}$ \\
\hline $\begin{array}{c}A \\
\text { 2954. } 8031 \\
\text { 2958. } 2284 \\
\text { 2966. } 1204 \\
\text { 2982. } 3150 \\
\text { 2984. } 4404\end{array}$ & $\begin{array}{l}5 \\
6 \\
4 \\
8 \\
5\end{array}$ & $\begin{array}{c}5 \times 10^{-4} \\
2 \\
3 \\
2 \\
4\end{array}$ & $\begin{array}{c}A \\
\text { 2953. } 9400 \\
\text { 2957. } 3646 \\
\text { 2965. } 2545 \\
\text { 2981. } 4450 \\
\text { 2983. } 5699\end{array}$ & $\begin{array}{c}A \\
3609.8885 \\
3619.7996 \\
3632.4985 \\
3648.8820 \\
3680.9608\end{array}$ & $\begin{array}{r}4 \\
4 \\
5 \\
5 \\
10\end{array}$ & $\begin{array}{c}5 \times 10^{-4} \\
3 \\
3 \\
4 \\
6\end{array}$ & $\begin{array}{c}A \\
\text { 3608. } 8591 \\
3618.7676 \\
3631.4632 \\
3647.8425 \\
3679.9131\end{array}$ \\
\hline $\begin{array}{l}\text { 2988. } 1618 \\
2995.3006 \\
3000.3863 \\
3001.8229 \\
3003.9057\end{array}$ & $\begin{array}{l}4 \\
6 \\
7 \\
7 \\
4\end{array}$ & $\begin{array}{l}5 \\
3 \\
4 \\
2 \\
5\end{array}$ & $\begin{array}{l}\text { 2987. } 2904 \\
\text { 2994. } 4274 \\
\text { 2999. } 5118 \\
3000.9481 \\
\text { 3003. } 0304\end{array}$ & $\begin{array}{l}3684.1026 \\
3688.5059 \\
3706.6203 \\
3710.3011 \\
3723.6219\end{array}$ & $\begin{array}{l}3 \\
9 \\
6 \\
7 \\
6\end{array}$ & $\begin{array}{l}4 \\
6 \\
3 \\
4\end{array}$ & $\begin{array}{l}3683.0541 \\
3687.4562 \\
3705.5660 \\
3709.2458 \\
3722.5631\end{array}$ \\
\hline $\begin{array}{l}3008.1588 \\
3009.0156 \\
3010.4463 \\
3018.5061 \\
3019.8621\end{array}$ & $\begin{array}{l}6 \\
5 \\
5 \\
4 \\
5\end{array}$ & $\begin{array}{l}6 \\
6 \\
3 \\
5 \\
4\end{array}$ & $\begin{array}{l}3007.2824 \\
3008.1390 \\
3009.5693 \\
3017.6271 \\
3018.9827\end{array}$ & $\begin{array}{l}3728.6787 \\
3734.3787 \\
3735.9262 \\
3738.1942 \\
3744.4255\end{array}$ & $\begin{array}{l}9 \\
8 \\
6 \\
6 \\
7\end{array}$ & $\begin{array}{l}5 \\
4 \\
5 \\
6 \\
5\end{array}$ & $\begin{array}{l}3727.6187 \\
3733.3172 \\
3734.8643 \\
3737.1317 \\
3743.3614\end{array}$ \\
\hline $\begin{array}{l}3021.3707 \\
3021.9526 \\
3024.9134 \\
3026.7234 \\
3027.3425\end{array}$ & $\begin{array}{l}2 \\
5 \\
8 \\
7 \\
3\end{array}$ & $\begin{array}{c}2 \\
4 \\
4 \\
\end{array}$ & $\begin{array}{l}3020.4909 \\
3021.0727 \\
3024.0328 \\
3025.8423 \\
3026.4612\end{array}$ & $\begin{array}{l}3746.9636 \\
3749.3272 \\
3750.5509 \\
3759.3006 \\
3764.8581\end{array}$ & $\begin{array}{l}2 \\
3 \\
6 \\
9 \\
9\end{array}$ & $\begin{array}{c}4 \\
4 \\
4\end{array}$ & $\begin{array}{l}3745.8988 \\
3748.2618 \\
3749.4852 \\
3758.2326 \\
3763.7887\end{array}$ \\
\hline $\begin{array}{l}3038.2725 \\
3041.3120 \\
3042.6232 \\
3043.5496 \\
3048.4905\end{array}$ & $\begin{array}{l}6 \\
6 \\
3 \\
4 \\
5\end{array}$ & $\begin{array}{l}3 \\
4 \\
-6 \\
4\end{array}$ & $\begin{array}{l}3037.3885 \\
3040.4272 \\
3041.7381 \\
3042.6643 \\
3047.6039\end{array}$ & $\begin{array}{l}3768.2617 \\
3788.9559 \\
3791.1683 \\
3796.0793 \\
3799.5895\end{array}$ & $\begin{array}{r}10 \\
7 \\
3 \\
9 \\
9\end{array}$ & $\begin{array}{c}6 \\
6 \\
--- \\
5 \\
5\end{array}$ & $\begin{array}{l}3767.1914 \\
3787.8802 \\
3790.0920 \\
3795.0017 \\
3798.5110\end{array}$ \\
\hline $\begin{array}{l}3058.3348 \\
3059.9753 \\
3068.1352 \\
3076.6129 \\
3084.6365\end{array}$ & $\begin{array}{l}6 \\
6 \\
7 \\
8 \\
3\end{array}$ & $\begin{array}{l}3 \\
3 \\
5 \\
6\end{array}$ & $\begin{array}{l}3057.4457 \\
3059.0859 \\
3067.2437 \\
3075.7193 \\
3083.7409\end{array}$ & $\begin{array}{l}3800.6254 \\
3814.1336 \\
3821.5092 \\
3825.5282 \\
3826.9664\end{array}$ & $\begin{array}{l}7 \\
6 \\
6 \\
8 \\
6\end{array}$ & $\begin{array}{l}4 \\
5 \\
7 \\
3 \\
7\end{array}$ & $\begin{array}{l}3799.5466 \\
3813.0514 \\
3820.4250 \\
3824.4430 \\
3825.8808\end{array}$ \\
\hline $\begin{array}{l}3100.8675 \\
3101.2030 \\
3101.5647 \\
3135.0182 \\
3194.1476\end{array}$ & $\begin{array}{l}6 \\
2 \\
6 \\
2 \\
4\end{array}$ & $\begin{array}{c}7 \\
--- \\
---\end{array}$ & $\begin{array}{l}3099.9678 \\
3100.3032 \\
3100.6649 \\
3134.1099 \\
3193.2245\end{array}$ & $\begin{array}{l}3835.3098 \\
3841.5270 \\
3842.1371 \\
3857.4648 \\
3861.0063\end{array}$ & $\begin{array}{l}9 \\
5 \\
5 \\
6 \\
5\end{array}$ & $\begin{array}{l}4 \\
8 \\
3 \\
6 \\
7\end{array}$ & $\begin{array}{l}3834.2220 \\
3840.4376 \\
3841.0475 \\
3856.3712 \\
3859.9119\end{array}$ \\
\hline $\begin{array}{l}3206.3221 \\
3237.1559 \\
3258.5329 \\
3441.9751 \\
3444.8631\end{array}$ & $\begin{array}{l}2 \\
5 \\
3 \\
4 \\
5\end{array}$ & $\begin{array}{c}4 \\
--- \\
4 \\
8\end{array}$ & $\begin{array}{l}3205.3959 \\
3236.2219 \\
3257.5935 \\
3440.9888 \\
3443.8761\end{array}$ & $\begin{array}{l}3866.6187 \\
3873.5985 \\
3879.1171 \\
3879.6722 \\
3887.3827\end{array}$ & $\begin{array}{l}6 \\
7 \\
5 \\
7 \\
8\end{array}$ & $\begin{array}{l}6 \\
4 \\
6 \\
5 \\
7\end{array}$ & $\begin{array}{l}3865.5228 \\
3872.5008 \\
3878.0179 \\
3878.5729 \\
3886.2812\end{array}$ \\
\hline $\begin{array}{l}3466.8528 \\
3476.4448 \\
3477.6974 \\
3491.5730 \\
3498.8415\end{array}$ & $\begin{array}{l}5 \\
4 \\
5 \\
5 \\
5\end{array}$ & $\begin{array}{l}8 \\
7 \\
6 \\
5 \\
6\end{array}$ & $\begin{array}{l}3465.8602 \\
3475.4497 \\
3476.7020 \\
3490.5740 \\
3497.8407\end{array}$ & $\begin{array}{l}3888.1489 \\
3899.1149 \\
3907.5856 \\
3921.3679 \\
3924.0221\end{array}$ & $\begin{array}{r}7 \\
2 \\
3 \\
7 \\
10\end{array}$ & $\begin{array}{c}5 \\
--- \\
--- \\
5\end{array}$ & $\begin{array}{l}3887.0474 \\
3898.0105 \\
3906.4791 \\
3920.2577 \\
3922.9112\end{array}$ \\
\hline $\begin{array}{l}3514.8227 \\
3522.2678 \\
3527.0478 \\
3555.9400 \\
3559.5313\end{array}$ & $\begin{array}{l}5 \\
4 \\
2 \\
3 \\
4\end{array}$ & $\begin{array}{c}5 \\
6 \\
-\cdots \\
---\end{array}$ & $\begin{array}{l}3513.8177 \\
3521.2610 \\
3526.0397 \\
3554.9245 \\
3558.5149\end{array}$ & $\begin{array}{l}3929.0314 \\
3931.4090 \\
3970.3796 \\
4006.3738 \\
4064.7414\end{array}$ & $\begin{array}{l}7 \\
7 \\
6 \\
5 \\
5\end{array}$ & $\begin{array}{l}4 \\
4 \\
5 \\
5 \\
5\end{array}$ & $\begin{array}{l}3927.9192 \\
3930.2962 \\
3969.2566 \\
4005.2414 \\
4063.5938\end{array}$ \\
\hline $\begin{array}{l}3566.3971 \\
3571.1157 \\
3588.0074\end{array}$ & $\begin{array}{l}4 \\
5 \\
3\end{array}$ & $\begin{array}{c}5 \\
10 \\
----\end{array}$ & $\begin{array}{l}3565.3789 \\
3570.0963 \\
3586.9836\end{array}$ & & & & \\
\hline
\end{tabular}


TABLE 2. Energy level differences

\begin{tabular}{|c|c|c|c|c|c|}
\hline \multirow{2}{*}{ Line } & \multirow{2}{*}{ Classification } & \multicolumn{2}{|c|}{ Wavenumber } & \multicolumn{2}{|c|}{ Wavenumber difference } \\
\hline & & $\begin{array}{l}\text { Electrodeless } \\
\text { discharge }\end{array}$ & $\begin{array}{l}\text { Arc in } \\
\text { air }\end{array}$ & $\begin{array}{l}\text { Electrodeless } \\
\text { discharge }\end{array}$ & $\begin{array}{l}\text { Arc in } \\
\text { air }\end{array}$ \\
\hline $\begin{array}{c}A \\
\text { 3825. } 5282 \\
3887.3827\end{array}$ & $\begin{array}{l}a{ }^{5} \mathrm{D}_{4}-z^{5} \mathrm{D}_{3} \\
a^{5} \mathrm{D}_{3}-z^{5} \mathrm{D}_{3}\end{array}$ & $\begin{array}{l}c m^{-1} \\
26140.181 \\
25724.249\end{array}$ & $\begin{array}{l}\mathrm{cm}^{-1} \\
0.18 \\
.23\end{array}$ & $\begin{array}{c}\mathrm{cm}^{-1} \\
415.932\end{array}$ & $\begin{array}{l}\mathrm{cm}^{-1} \\
0.95\end{array}$ \\
\hline $\begin{array}{l}\text { 3861. } 0063 \\
3924.0221\end{array}$ & $\begin{array}{l}a{ }^{5} \mathrm{D}_{4}-z^{5} \mathrm{D}_{4} \\
a^{5} \mathrm{D}_{3}-z^{5} \mathrm{D}_{4}\end{array}$ & $\begin{array}{l}25899.984 \\
25484.056\end{array}$ & $\begin{array}{l}.98 \\
.04\end{array}$ & 415. 928 & .94 \\
\hline $\begin{array}{l}3680.9608 \\
3738.1942\end{array}$ & $\begin{array}{l}a^{5} \mathrm{D}_{4}-z^{5} \mathrm{~F}_{4} \\
a^{5} \mathrm{D}_{3}-z^{5} \mathrm{~F}_{4}\end{array}$ & $\begin{array}{l}27166.820 \\
26750.884\end{array}$ & $\begin{array}{l}80 \\
.87\end{array}$ & 415. 936 & .93 \\
\hline $\begin{array}{l}2984.4404 \\
3021.9526\end{array}$ & $\begin{array}{l}a^{5}{ }^{5} \mathrm{D}_{4}-y^{5} \mathrm{D}_{3} \\
a^{5} \mathrm{D}_{3}-y^{5} \mathrm{D}_{3}\end{array}$ & $\begin{array}{l}\text { 33507. } 119 \\
\text { 33091. } 187\end{array}$ & - - - - & 415. 932 & \\
\hline $\begin{array}{l}\text { 3194. } 1476 \\
3237.1559\end{array}$ & $\begin{array}{l}a^{5} \mathrm{D}_{4}-z^{3} \mathrm{~F}_{4} \\
a^{5} \mathrm{D}_{3}-z^{3} \mathrm{~F}_{4}\end{array}$ & $\begin{array}{l}\text { 31307. } 257 \\
30891.314\end{array}$ & 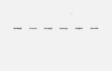 & 415. 943 & \\
\hline $\begin{array}{l}\text { 3887. } 3827 \\
3931.4090\end{array}$ & $\begin{array}{l}a^{5} \mathrm{D}_{3}-z^{5} \mathrm{D}_{3} \\
a^{5} \mathrm{D}_{2}-z^{5} \mathrm{D}_{3}\end{array}$ & $\begin{array}{l}25724.249 \\
25436.173\end{array}$ & $\begin{array}{l}.23 \\
.15\end{array}$ & 288. 076 & 08 \\
\hline $\begin{array}{l}3684.1026 \\
3723.6219\end{array}$ & $\begin{array}{l}a^{5} \mathrm{D}_{3}-z^{5} \mathrm{~F}_{2} \\
a^{5} \mathrm{D}_{2}-z^{5} \mathrm{~F}_{2}\end{array}$ & $\begin{array}{l}27143.652 \\
26855.573\end{array}$ & $-\ldots-\ldots$ & 288. 079 & \\
\hline $\begin{array}{l}3441.9751 \\
3476.4448\end{array}$ & $\begin{array}{l}a^{5} \mathrm{D}_{3}-z{ }^{5} \mathrm{P}_{2} \\
a^{5} \mathrm{D}_{2}-z^{5} \mathrm{P}_{2}\end{array}$ & $\begin{array}{l}29053.086 \\
28765.019\end{array}$ & $\ldots \ldots$ & 288. 067 & \\
\hline $\begin{array}{l}3491.5730 \\
3527.0478\end{array}$ & $\begin{array}{l}a^{5} \mathrm{D}_{3}-z^{5} \mathrm{P}_{3} \\
a^{5} \mathrm{D}_{2}-z^{5} \mathrm{P}_{3}\end{array}$ & $\begin{array}{l}28640.386 \\
28352.323\end{array}$ & - n- - & 288. 063 & \\
\hline $\begin{array}{l}3021.9526 \\
3048.4905\end{array}$ & $\begin{array}{l}a{ }^{5} \mathrm{D}_{3}-y{ }^{5} \mathrm{D}_{3} \\
a^{5} \mathrm{D}_{2}-y{ }^{5} \mathrm{D}_{3}\end{array}$ & $\begin{array}{l}33091.187 \\
32803.120\end{array}$ & $-\ldots \ldots$ & 288. 067 & \\
\hline $\begin{array}{l}\text { 2995. } 3006 \\
3021.3707\end{array}$ & $\begin{array}{l}a^{5} \mathrm{D}_{3}-y{ }^{5} \mathrm{D}_{2} \\
a^{5} \mathrm{D}_{2}-y^{5} \mathrm{D}_{2}\end{array}$ & $\begin{array}{l}\text { 33385. } 631 \\
33097.561\end{array}$ & - . - - & 288. 070 & \\
\hline $\begin{array}{l}\text { 2982. } 3150 \\
\text { 3008. } 1588\end{array}$ & $\begin{array}{l}a^{5} \mathrm{D}_{3}-z^{3} \mathrm{P}_{2} \\
a^{5} \mathrm{D}_{2}-z^{3} \mathrm{P}_{2}\end{array}$ & $\begin{array}{l}33530.999 \\
33242.926\end{array}$ & - .... & 288. 073 & \\
\hline $\begin{array}{l}3879.6722 \\
3907.5856\end{array}$ & $\begin{array}{l}a^{5}{ }^{5} \mathrm{D}_{2}-z^{5} \mathrm{D}_{1} \\
a^{5} \mathrm{D}_{1}-z^{5} \mathrm{D}_{1}\end{array}$ & $\begin{array}{l}25775.373 \\
25591.250\end{array}$ & $\begin{array}{l}.36 \\
.23\end{array}$ & 184. 123 & .13 \\
\hline $\begin{array}{l}3723.6219 \\
3749.3272\end{array}$ & $\begin{array}{l}a^{5}{ }^{5} \mathrm{D}_{2}-z^{5} \mathrm{~F}_{2} \\
a^{5} \mathrm{D}_{1}-z^{5} \mathrm{~F}_{2}\end{array}$ & $\begin{array}{l}26855.573 \\
26671.452\end{array}$ & $\begin{array}{l}.56 \\
.44\end{array}$ & 184. 121 & 12 \\
\hline $\begin{array}{l}\text { 3444. } 8631 \\
3466.8528\end{array}$ & $\begin{array}{l}a^{5} \mathrm{D}_{2}-z{ }^{5} \mathrm{P}_{1} \\
a^{5} \mathrm{D}_{1}-z^{5} \mathrm{P}_{1}\end{array}$ & $\begin{array}{l}29028.730 \\
28844.605\end{array}$ & $\begin{array}{l}.71 \\
.58\end{array}$ & 184. 125 & 13 \\
\hline $\begin{array}{l}3476.4448 \\
3498.8415\end{array}$ & $\begin{array}{l}a{ }^{5} \mathrm{D}_{2}-z^{5} \mathrm{P}_{2} \\
a^{5} \mathrm{D}_{1}-z^{5} \mathrm{P}_{2}\end{array}$ & $\begin{array}{l}28765.019 \\
28580.889\end{array}$ & $\ldots+\cdots$ & 184. 130 & \\
\hline $\begin{array}{l}\text { 3021. } 3707 \\
\text { 3038. } 2725\end{array}$ & $\begin{array}{l}a^{5}{ }^{5} \mathrm{D}_{2}-y{ }^{5} \mathrm{D}_{2} \\
a^{5} \mathrm{D}_{1}-y{ }^{5} \mathrm{D}_{2}\end{array}$ & $\begin{array}{l}33097.561 \\
32913.440\end{array}$ & $-\ldots-$. & 184. 121 & \\
\hline $\begin{array}{l}3001.8229 \\
3018.5061\end{array}$ & $\begin{array}{l}a{ }^{5} \mathrm{D}_{2}-y{ }^{5} \mathrm{D}_{1} \\
a^{5} \mathrm{D}_{1}-y^{5} \mathrm{D}_{1}\end{array}$ & $\begin{array}{l}\text { 33313. } 091 \\
\text { 33128. } 971\end{array}$ & $\ldots \ldots$ & 184. 120 & \\
\hline $\begin{array}{l}3008.1588 \\
3024.9134\end{array}$ & $\begin{array}{l}a{ }^{5} \mathrm{D}_{2}-z^{3} \mathrm{P}_{2} \\
a^{5} \mathrm{D}_{1}-z^{3} \mathrm{P}_{2}\end{array}$ & $\begin{array}{l}\text { 33242. } 926 \\
\text { 33058. } 798\end{array}$ & & 184. 128 & \\
\hline $\begin{array}{l}3907.5856 \\
3921.3679\end{array}$ & $\begin{array}{l}a^{5} \mathrm{D}_{1}-z^{5} \mathrm{D}_{1} \\
a^{5} \mathrm{D}_{0}-z^{5} \mathrm{D}_{1}\end{array}$ & $\begin{array}{l}\text { 25591. } 250 \\
\text { 25501. } 305\end{array}$ & $\begin{array}{l}.23 \\
.29\end{array}$ & 89.945 & .94 \\
\hline $\begin{array}{l}\text { 3734. } 3787 \\
3746.9636\end{array}$ & $\begin{array}{l}a^{5}{ }^{5} \mathrm{D}_{1}-z^{5} \mathrm{~F}_{1} \\
a^{5} \mathrm{D}_{0}-z^{5} \mathrm{~F}_{1}\end{array}$ & $\begin{array}{l}\text { 26778. } 216 \\
\text { 26688. } 276\end{array}$ & $-\ldots+-$ & 89. 940 & \\
\hline $\begin{array}{l}3466.8528 \\
3477.6974\end{array}$ & $\begin{array}{l}a^{5} \mathrm{D}_{1}-z{ }^{5} \mathrm{P}_{1} \\
a^{5} \mathrm{D}_{0}-z{ }^{5} \mathrm{P}_{1}\end{array}$ & $\begin{array}{l}28844.605 \\
28754.658\end{array}$ & $\begin{array}{l}.58 \\
.64\end{array}$ & 89. 947 & .94 \\
\hline $\begin{array}{l}\text { 3018. } 5061 \\
3026.7234\end{array}$ & $\begin{array}{l}a^{5} \mathrm{D}_{1}-y{ }^{5} \mathrm{D}_{1} \\
a^{5} \mathrm{D}_{0}-y{ }^{5} \mathrm{D}_{1}\end{array}$ & $\begin{array}{l}33128.971 \\
33039.028\end{array}$ & $-\ldots$ & 89. 943 & \\
\hline
\end{tabular}


TaBle 2. Energy level differences-Continued

\begin{tabular}{|c|c|c|c|c|c|}
\hline \multirow{2}{*}{ Line } & \multirow{2}{*}{ Classification } & \multicolumn{2}{|c|}{ Wavenumber } & \multicolumn{2}{|c|}{ Wavenumber difference } \\
\hline & & $\begin{array}{l}\text { Electrodeless } \\
\text { discharge }\end{array}$ & $\begin{array}{l}\text { Arc in } \\
\text { air }\end{array}$ & $\begin{array}{c}\text { Electrodeless } \\
\text { discharge }\end{array}$ & $\begin{array}{l}\text { Arc in } \\
\text { air }\end{array}$ \\
\hline $\begin{array}{c}A \\
\text { 2958. } 2284 \\
2966.1204\end{array}$ & $\begin{array}{l}a{ }^{5} \mathrm{D}_{1}-y{ }^{5} \mathrm{~F}_{1} \\
a^{5} \mathrm{D}_{0}-y{ }^{5} \mathrm{~F}_{1}\end{array}$ & $\begin{array}{c}\mathrm{cm}^{-1} \\
33804.016 \\
33714.073\end{array}$ & $\begin{array}{l}c m^{-1} \\
0.01 \\
.07\end{array}$ & $\begin{array}{l}\mathrm{cm}^{-1} \\
89.943\end{array}$ & $\begin{array}{l}\mathrm{cm}^{-1} \\
0.94\end{array}$ \\
\hline $\begin{array}{l}3821.5092 \\
3888.1489\end{array}$ & $\begin{array}{l}a^{5}{ }^{5} \mathrm{~F}_{5}-y{ }^{5} \mathrm{D}_{4} \\
a^{5} \mathrm{~F}_{4}-y^{5} \mathrm{D}_{4}\end{array}$ & $\begin{array}{l}26167.672 \\
25719.180\end{array}$ & -.... & 448. 492 & \\
\hline $\begin{array}{l}3688.5059 \\
3750.5509\end{array}$ & $\begin{array}{l}a^{5} \mathrm{~F}_{5}-y{ }^{5} \mathrm{~F}_{4} \\
a^{5} \mathrm{~F}_{4}-y{ }^{5} \mathrm{~F}_{4}\end{array}$ & $\begin{array}{l}\text { 27111. } 248 \\
26662.750\end{array}$ & $\begin{array}{l}.23 \\
.73\end{array}$ & 448. 498 & .50 \\
\hline $\begin{array}{l}3735.9262 \\
3799.5895\end{array}$ & $\begin{array}{l}a^{5} \mathrm{~F}_{5}-y^{5} \mathrm{~F}_{5} \\
a^{5} \mathrm{~F}_{4}-y^{5} \mathrm{~F}_{5}\end{array}$ & $\begin{array}{l}\text { 26767. } 124 \\
\text { 26318. } 633\end{array}$ & $\begin{array}{l}.10 \\
.62\end{array}$ & 448. 491 & 48 \\
\hline $\begin{array}{l}3514.8227 \\
3571.1157\end{array}$ & $\begin{array}{l}a^{5} \mathrm{~F}_{5}-z^{3} \mathrm{G}_{5} \\
a^{5} \mathrm{~F}_{4}-z^{3} \mathrm{G}_{5}\end{array}$ & $\begin{array}{l}28450.937 \\
28002.453\end{array}$ & $\ldots \ldots$ & 448. 484 & \\
\hline $\begin{array}{l}3058.3348 \\
3100.8675\end{array}$ & $\begin{array}{l}a{ }^{5} \mathrm{~F}_{5}-x{ }^{5} \mathrm{D}_{4} \\
a^{5} \mathrm{~F}_{4}-x{ }^{5} \mathrm{D}_{4}\end{array}$ & $\begin{array}{l}32697.532 \\
32249.040\end{array}$ & $-\ldots--$ & 448. 492 & \\
\hline $\begin{array}{l}3000.3863 \\
3041.3120\end{array}$ & $\begin{array}{l}a^{5} \mathrm{~F}_{5}-x^{5} \mathrm{~F}_{5} \\
a^{5} \mathrm{~F}_{4}-x^{5} \mathrm{~F}_{5}\end{array}$ & $\begin{array}{l}33329.042 \\
32880.546\end{array}$ & $\ldots+\ldots$ & 448. 496 & \\
\hline $\begin{array}{l}\text { 3826. } 9664 \\
3879.1171\end{array}$ & $\begin{array}{l}a{ }^{5} \mathrm{~F}_{4}-y{ }^{5} \mathrm{D}_{3} \\
a^{5} \mathrm{~F}_{3}-y^{5} \mathrm{D}_{3}\end{array}$ & $\begin{array}{l}26130.357 \\
25779.062\end{array}$ & $\begin{array}{l}.33 \\
.04\end{array}$ & 351. 295 & .29 \\
\hline $\begin{array}{l}3750.5509 \\
3800.6254\end{array}$ & $\begin{array}{l}a^{5} \mathrm{~F}_{4}-y{ }^{5} \mathrm{~F}_{4} \\
a^{5} \mathrm{~F}_{3}-y{ }^{5} \mathrm{~F}_{4}\end{array}$ & $\begin{array}{l}\text { 26662. } 750 \\
\text { 26311. } 459\end{array}$ & $\begin{array}{l}.73 \\
.44\end{array}$ & 351. 291 & .29 \\
\hline $\begin{array}{l}3710.3011 \\
3759.3006\end{array}$ & $\begin{array}{l}a^{5} \mathrm{~F}_{4}-y{ }^{5} \mathrm{~F}_{3} \\
a^{5} \mathrm{~F}_{3}-y^{5} \mathrm{~F}_{3}\end{array}$ & $\begin{array}{l}\text { 26951. } 990 \\
26600.693\end{array}$ & $-\ldots-$ & 351. 297 & \\
\hline $\begin{array}{l}\text { 3522. } 2678 \\
3566.3971\end{array}$ & $\begin{array}{l}a{ }^{5} \mathrm{~F}_{4}-z^{3} \mathrm{G}_{4} \\
a^{5} \mathrm{~F}_{3}-z^{3} \mathrm{G}_{4}\end{array}$ & $\begin{array}{l}28390.800 \\
28039.502\end{array}$ & $\begin{array}{l}.77 \\
.49\end{array}$ & 351. 298 & .28 \\
\hline $\begin{array}{l}3068.1352 \\
3101.5647\end{array}$ & $\begin{array}{l}a{ }^{5} \mathrm{~F}_{4}-x{ }^{5} \mathrm{D}_{3} \\
a^{5} \mathrm{~F}_{3}-x{ }^{5} \mathrm{D}_{3}\end{array}$ & $\begin{array}{l}\text { 32593. } 088 \\
\text { 32241. } 791\end{array}$ & - - - - - & 351. 297 & \\
\hline $\begin{array}{l}3100.8675 \\
3135.0182\end{array}$ & $\begin{array}{l}a^{5} \mathrm{~F}_{4}-x{ }^{5} \mathrm{D}_{4} \\
a^{5} \mathrm{~F}_{3}-x^{5} \mathrm{D}_{4}\end{array}$ & $\begin{array}{l}32249.040 \\
31897.741\end{array}$ & ...... & 351. 299 & \\
\hline $\begin{array}{l}3010.4463 \\
3042.6232\end{array}$ & $\begin{array}{l}a^{5} \mathrm{~F}_{4}-x^{5} \mathrm{~F}_{4} \\
a^{5} \mathrm{~F}_{3}-x^{5} \mathrm{~F}_{4}\end{array}$ & $\begin{array}{l}33217.666 \\
32866.377\end{array}$ & & 351. 289 & \\
\hline $\begin{array}{l}\text { 2988. } 1618 \\
3019.8621\end{array}$ & $\begin{array}{l}a^{5} \mathrm{~F}_{4}-x^{5} \mathrm{~F}_{3} \\
a^{5} \mathrm{~F}_{3}-x^{5} \mathrm{~F}_{3}\end{array}$ & $\begin{array}{l}33465.390 \\
33114.095\end{array}$ & -.... & 351. 295 & \\
\hline $\begin{array}{l}3835.3098 \\
3873.5985\end{array}$ & $\begin{array}{l}a{ }^{5} \mathrm{~F}_{3}-y{ }^{5} \mathrm{D}_{2} \\
a^{5} \mathrm{~F}_{2}-y{ }^{5} \mathrm{D}_{2}\end{array}$ & $\begin{array}{l}26073.513 \\
25815.789\end{array}$ & $\begin{array}{l}49 \\
.77\end{array}$ & 257. 724 & .72 \\
\hline $\begin{array}{l}3759.3006 \\
3796.0793\end{array}$ & $\begin{array}{l}a{ }^{5} \mathrm{~F}_{3}-y^{5} \mathrm{~F}_{3} \\
a^{5} \mathrm{~F}_{2}-y^{5} \mathrm{~F}_{3}\end{array}$ & $\begin{array}{l}26600.693 \\
26342.969\end{array}$ & $\begin{array}{l}.68 \\
.95\end{array}$ & 257. 724 & .73 \\
\hline $\begin{array}{l}3728.6787 \\
3764.8581\end{array}$ & $\begin{array}{l}a^{5} \mathrm{~F}_{3}-y^{5} \mathrm{~F}_{2} \\
a^{5} \mathrm{~F}_{2}-y^{5} \mathrm{~F}_{2}\end{array}$ & $\begin{array}{l}26819.152 \\
26561.426\end{array}$ & $\begin{array}{l}.14 \\
.42\end{array}$ & 257. 726 & .72 \\
\hline $\begin{array}{l}3076.6129 \\
3101.2030\end{array}$ & $\begin{array}{l}a{ }^{5} \mathrm{~F}_{3}-x{ }^{5} \mathrm{D}_{2} \\
a^{5} \mathrm{~F}_{2}-x{ }^{5} \mathrm{D}_{2}\end{array}$ & $\begin{array}{l}32503.277 \\
32245.551\end{array}$ & & 257. 726 & 8 \\
\hline $\begin{array}{l}3019.8621 \\
3043.5496\end{array}$ & $\begin{array}{l}a^{5} \mathrm{~F}_{3}-x^{5} \mathrm{~F}_{3} \\
a^{5} \mathrm{~F}_{2}-x^{5} \mathrm{~F}_{3}\end{array}$ & $\begin{array}{l}33114.095 \\
32856.373\end{array}$ & $-\ldots-$ & 257. 722 & \\
\hline $\begin{array}{l}3003.9057 \\
3027.3425\end{array}$ & $\begin{array}{l}a^{5} \mathrm{~F}_{3}-x^{5} \mathrm{~F}_{2} \\
a^{5} \mathrm{~F}_{2}-x^{5} \mathrm{~F}_{2}\end{array}$ & $\begin{array}{l}33289.993 \\
33032.272\end{array}$ & -.... & 257. 721 & \\
\hline $\begin{array}{l}3841.5270 \\
3866.6187\end{array}$ & $\begin{array}{l}a{ }^{5} \mathrm{~F}_{2}-y{ }^{5} \mathrm{D}_{1} \\
a^{5} \mathrm{~F}_{1}-y{ }^{5} \mathrm{D}_{1}\end{array}$ & $\begin{array}{l}26031.315 \\
25862.390\end{array}$ & $\begin{array}{l}.31 \\
.37\end{array}$ & 168. 925 & .94 \\
\hline $\begin{array}{l}\text { 3873. } 5985 \\
\text { 3899. } 1149\end{array}$ & $\begin{array}{l}a^{5}{ }^{5} \mathrm{~F}_{2}-y{ }^{5} \mathrm{D}_{2} \\
a^{5} \mathrm{~F}_{1}-y^{5} \mathrm{D}_{2}\end{array}$ & $\begin{array}{l}25815.789 \\
25646.846\end{array}$ &.--- & 168. 943 & \\
\hline
\end{tabular}


TABLE 2. Energy level differences-Continued

\begin{tabular}{|c|c|c|c|c|c|}
\hline \multirow{2}{*}{ Line } & \multirow{2}{*}{ Classification } & \multicolumn{2}{|c|}{ Wavenumber } & \multicolumn{2}{|c|}{ Wavenumber difference } \\
\hline & & $\begin{array}{l}\text { Electrodeless } \\
\text { discharge }\end{array}$ & $\begin{array}{l}\text { Arc in } \\
\text { air }\end{array}$ & $\begin{array}{l}\text { Electrodeless } \\
\text { discharge }\end{array}$ & $\begin{array}{l}\text { Are in } \\
\text { air }\end{array}$ \\
\hline $\begin{array}{c}A \\
\text { 3764. } 8581 \\
3788.9559\end{array}$ & $\begin{array}{l}a^{5} \mathrm{~F}_{2}-y^{5} \mathrm{~F}_{2} \\
a^{5} \mathrm{~F}_{1}-y^{5} \mathrm{~F}_{2}\end{array}$ & $\begin{array}{c}\mathrm{cm}^{-1} \\
\text { 26561. } 426 \\
26392.495\end{array}$ & $\begin{array}{r}c m^{-1} \\
0.42 \\
.47\end{array}$ & $\begin{array}{c}\mathrm{cm}^{-1} \\
168.931\end{array}$ & $\begin{array}{l}\mathrm{cm}^{-1} \\
0.95\end{array}$ \\
\hline $\begin{array}{l}3744.4255 \\
3768.2617\end{array}$ & $\begin{array}{l}a^{5} \mathrm{~F}_{2}-y{ }^{5} \mathrm{~F}_{1} \\
a^{5} \mathrm{~F}_{1}-y^{5} \mathbf{F}_{1}\end{array}$ & $\begin{array}{l}\text { 26706. } 367 \\
26537.435\end{array}$ & $\ldots \ldots$ & 168. 932 & \\
\hline $\begin{array}{l}3588.0074 \\
3609.8885\end{array}$ & $\begin{array}{l}a^{5} \mathrm{~F}_{2}-z^{5} \mathrm{G}_{2} \\
a^{5} \mathrm{~F}_{1}-z^{5} \mathrm{G}_{2}\end{array}$ & $\begin{array}{l}27870.623 \\
27701.687\end{array}$ & -....- & 168. 936 & \\
\hline
\end{tabular}

TABLE 3. Comparison of wavelengths from the electrodeless lamp and the hollow-cathode discharge

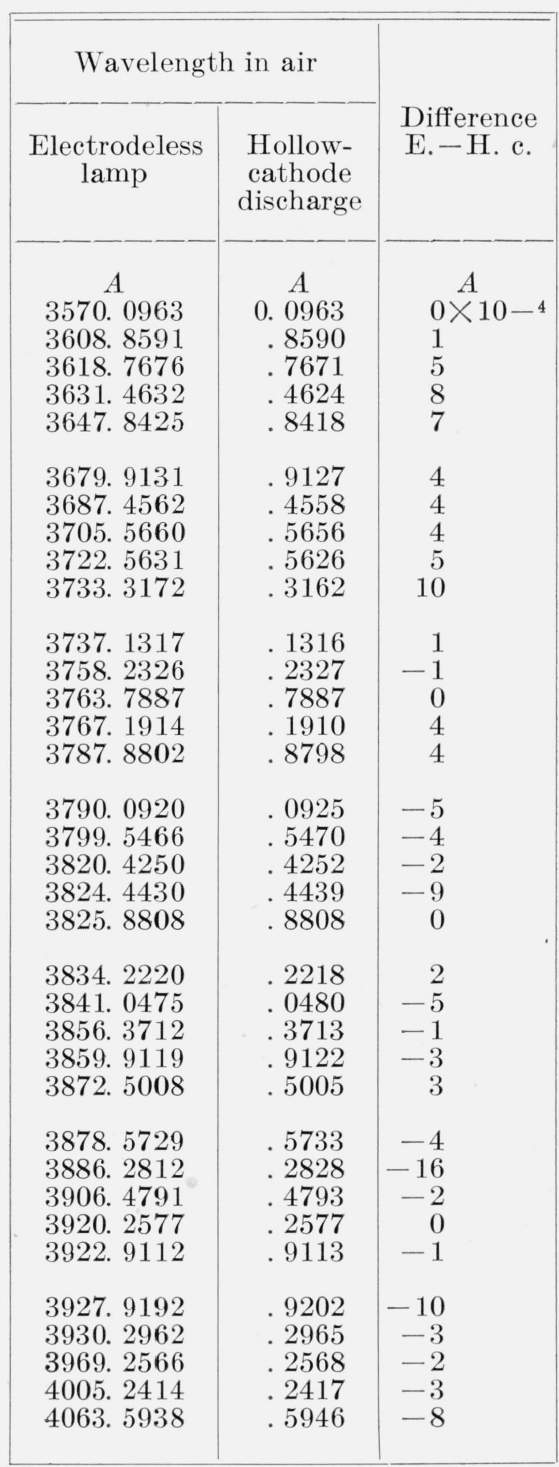

wavelengths. This demonstrates that the wavelengths of iron radiations from iron-halide lamps can easily be measured with greater accuracy than those from the international iron arc

As a further illustration of the accuracy obtained from low-pressure iron sources, the wavelengths from the electrodeless tube are compared to the wavelengths measured earlier by Stanley and Dieke [15] in the hollow-cathode discharge. Table 3 contains the air wavelengths of all lines common to the two sets of measurements. The hollow-cathode wavelengths have been revised on account of refinements in the $\mathrm{Hg}^{198}$ standards that have been made since the hollow-cathode wavelengths were published. The required corrections vary from $-0.0001 \mathrm{~A}$ at $3570 \mathrm{~A}$ to $-0.0003 \mathrm{~A}$ at $4063 \mathrm{~A}$. The average probable error for the 35 lines involved is $0.0005 \mathrm{~A}$ for the electrodeless wavelengths and $0.0006 \mathrm{~A}$ for the hollow-cathode wavelengths. The measurements from the two sources are well within the expected uncertainty, 17 of the differences being less than or equal to $0.0003 \mathrm{~A}$ and 18 of the differences being greater than $0.0003 \mathrm{~A}$. It should be noted, however, that below 3789 A the hollow-cathode wavelengths are generally less than the electrodeless wavelengths by about $0.0004 \mathrm{~A}$, and above $3789 \mathrm{~A}$ the hollow-cathode wavelengths are greater on the average by the same amount. There are not sufficient data to determine the cause of this discrepancy, or whether any significance is to be attached to it.

One of the authors (RWS) expresses his gratitude to the Division of Research and Industrial Service of Clarkson College of Technology for a grant that supported this work at Clarkson during the academic year 1955-1956. Thanks are also due to Charles Allen for his painstaking measurement of interference patterns and calculation of fractional parts for more than one-third of the individual lines. 


\section{References}

[1] H. Kayser and C. Runge, Anhang zu den Abhandlungen der Kön, Akad. Wiss. zu Berlin, p. 1 (1888) ; H. Kayser, Astrophys. J. 13, 329 (1901).

[2] Ch. Fabry and A. Perot, Ann. chim. et. phys. [7] 25, 98 (1902); Astrophys. J. 15, 73 and 261 (1902).

[3] H. Buisson and Ch. Fabry, J. Physique [5] 2, 442 (1912).

[4] Trans. Int. Union Cooperation in Solar Research 1, 230 (1906).

[5] Trans. Int. Union Cooperation in Solar Research 2, 20 (1908).

[6] Trans. Int. Union Cooperation in Solar Research 3, 139 (1911)

[7] Trans. Int. Astron. Union 1, 35 (1922).

[8] Trans. Int. Astron. Union 3, 77 (1928).

[9] Trans. Int. Astron. Union 6, 79 (1938).

[10] Trans. Int. Astron. Union 9, (1956)

[11] K. Burns and F. M. Walters, Jr., Publs. Allegheny Observatory 6, No. 11, 159 (1929); 8, No. 4, 39 (1931).
[12] Trans. Int. Astron. Union 2, 43 (1925).

[13] W. E. Williams and A. Middleton, Proc. Roy. Soc. (London) [A] 172, 159 (1939).

[14] H. M. Crosswhite, G. H. Dieke, and C. S. Legagneur, J. Opt. Soc. Am. 45, 270 (1955).

[15] R. W. Stanley and G. H. Dieke, J. Opt. Soc. Am. 45, 280 (1955).

[16] C. H. Corliss, W. R. Bozman, and F. O. Westfall, J. Opt. Soc. Am. 43, 398 (1953).

[17] W. F. Meggers and F. O. Westfall, J. Research NBS 44, 447 (1950) RP2091.

[18] F. H. Rolt and H. Barrell, Proc. Roy. Soc. (London) [A] 122, 131 (1929).

[19] W. F. Meggers and C. J. Humphreys, J. Research NBS 18, 543 (1937) RP992.

[20] K. G. Kessler and W. F. Meggers, J. Opt. Soc. Am. 45, 902 (1955).

[21] B. Edlén, J. Opt. Soc. Am. 43, 339 (1953).

Washington, August 28, 1956. 